\title{
A1CF Gene
}

National Cancer Institute

\section{Source}

National Cancer Institute. A1CF Gene. NCI Thesaurus. Code C143031.

This gene is involved in the deamination of APOB mRNA. 